\title{
THE EFFECT OF ALLOXAN DIABETES AND ACIDOSIS ON THE MINERAL AND WATER CONTENT OF BONE 1,2
}

\author{
By NANCY NICHOLS AND GEORGE NICHOLS, JR. ${ }^{3}$ \\ (From the Baker Clinic Research Laboratory, New England Deaconess Hospital, and the \\ Departments of Medicine and Biochemistry, Harvard Medical School, Boston, Mass.)
}

(Submitted for publication April 28, 1958; accepted July 31, 1958)

Depletion of the body stores of fixed base is the most serious complication of diabetic ketoacidosis, and losses of total body sodium of 25 to 50 per cent have been reported in diabetic acidosis in man (1-4). Recent work from several laboratories has indicated that from 30 to 45 per cent of the total body sodium exists out of solution in the mineral solids of the skeleton (5-7). It has also been demonstrated that this store of sodium is not fixed but may increase or decrease depending on whether the individual is subjected to excess sodium intake, uncompensated sodium loss or acidosis $(8-10)$. The degree to which the bone sodium pool may be reduced seems to vary with the intensity and duration of the sodium loss and acidosis (7) and probably with the age of the animal $(7,8,11)$. Therefore, experiments designed to examine effects of diabetes and of acidosis, separately and together, upon the size of this store of body sodium should be of value in designing rational electrolyte replacement therapy in diabetic acidosis.

In the experiments reported here the bone sodium content of rats with alloxan diabetes of both short and long duration was compared with normal controls of equal age. In addition, normal and diabetic rats were rendered acidotic by the intraperitoneal injection of ammonium chloride and the response of their bone sodium to this stimulus was examined. The results indicated that untreated alloxan diabetes, in the absence of acidosis, as indicated by normal blood $\mathrm{pH}$ 's, had no effect on bone sodium stores, and that both normal and diabetic animals responded to acidosis with a comparable decrease of about 12 per cent in bone crystal sodium content.

\footnotetext{
1 Supported by Public Health Service Grant A-525 and National Science Foundation Grant G-1307.

2 Presented in part before the Twentieth International Congress of Physiology, Brussels, Belgium, August, 1956.

8 Markle Scholar in Medical Science.
}

\section{METHODS AND CALCULATIONS}

All of these studies were carried out in male, albino rats of the Charles River strain, weighing 225 to 250 Gm., 9 to 10 weeks old at the initiation of the experiment. All of the animals were maintained, two to a cage, on an ad libitum diet of Purina Rat Checkers and tap water. All of the animals were fasted for 20 hours prior to sacrifice. The control animals for each group were obtained from the supplier at the same time as their experimental counterparts, and were maintained under identical conditions.

Diabetes was induced by the intravenous injection of alloxan monohydrate ( $40 \mathrm{mg}$. per $\mathrm{Kg}$.) following a 24 hour fast. Criteria for the establishment of diabetes were two random blood sugar levels of over $300 \mathrm{mg}$. per cent one and two weeks after injection, together with a failure to gain weight in a normal fashion. Rats who became severely ill within 24 to 48 hours of alloxan injection were sacrificed and not used in this study, since we had previously found, at sacrifice and autopsy, that these animals had severe renal and hepatic damage, in addition to destruction of the beta cells of the pancreas, and abnormalities of these organs, especially the kidneys, might be expected to produce changes in the water and electrolyte content of the tissues, independent of the effects of diabetes. One group of diabetic rats was sacrificed three to four weeks after the injection of alloxan. Another group of diabetic rats was sacrificed at the same time following the induction of acidosis, together with a group of normal controls and nondiabetic acidotic animals. A third group of eight diabetic rats, together with six controls, was maintained for 23 weeks. During the twenty-third week two of the diabetic animals died, so the remaining six were sacrificed at that time, approximately six months after the establishment of diabetes. No insulin was administered to any of the diabetic animals.

Acidosis was induced by the intraperitoneal injection of normal saline, to which was added ammonium chloride (100 mM per L.). Eight $\mathrm{ml}$. per $100 \mathrm{Gm}$. of body weight was administered four hours prior to sacrifice. It must be noted that ketoacidosis is almost impossible to induce in the alloxan-diabetic animal, since once diabetes has been established by this drug; loss of body fat occurs almost immediately unless insulin is administered, and within two to three weeks the fat depots have practically disappeared. Accordingly, aceto-acetic acid and other ketones in increased amounts do not appear in the plasma of these animals, presumably due to a lack of fatty acids 
for metabolism, and intense, true ketoacidosis cannot therefore be produced. However, moderately severe hyperchloremic acidosis resulted from the procedure used here.

At sacrifice the rats were exsanguinated through the abdominal aorta under Nembutal ${ }^{\circledR}$ anaesthesia. $\mathrm{A}$ pH determination (using a glass electrode and a Model G Beckman $\mathrm{pH}$ meter) and a blood-sugar (by the FolinMalmros method) were performed immediately on the whole blood. One fasted, alloxanized rat with a blood sugar of less than $200 \mathrm{mg}$. per cent was discarded and four rats given ammonium chloride who exhibited a $\mathrm{pH}$ of more than 7.32 were also excluded from the experiment. No analyses were performed on the bones of these animals. A semi-quantitative analysis for ketones [by the nitroprusside method (12)] was carried out on the plasma of each rat. Plasma water was determined by means of a micropyknometer, plasma chlorides by the method of Wilson and Ball (13), and plasma sodium by means of an internal standard flame photometer (14), built by the authors. Because of the small amount of blood available, blood and plasma analyses were not carried out in duplicate.

Both femurs were removed for analysis. They were carefully scraped free of all adherent tissue, and the epi- physes removed with a small bone-cutter. The marrow was removed from the shaft by means of small wires. All possible precautions were taken to carry out these processes in a uniform, rapid manner and to avoid contamination with electrolytes or loss of water by evaporation.

Both femurs from each animal were placed in a tared weighing bottle and brought to constant weight at $102^{\circ} \mathrm{C}$. The bones were then ground by hand in a mortar to a powder the consistency of fine talc. This powder was extracted three times with a mixture of equal parts of ethyl and petroleum ether to remove neutral fat. The marrow-free bones of young rats contain almost no fat (less than 1 per cent). However, the bones of the older animals contained significant amounts of fat (up to 5 per cent of wet weight). Therefore, all bones were fatextracted. The methods used in the analysis of the bones for chloride and sodium have been described in detail elsewhere (9). Bone chloride and sodium analyses were all carried out in duplicate. Ashing was carried out on separate samples of 75 to $100 \mathrm{mg}$. The samples were ashed in platinum crucibles for 48 hours at $1,000^{\circ} \mathrm{F}$.

Calculation of the crystal sodium, or that part of the sodium not contained in the extracellular fluid of the bone, was made on the assumption that all of the chloride pres-

TABLE I

Basic data

\begin{tabular}{|c|c|c|c|c|c|c|}
\hline & & $\begin{array}{l}\text { Duration } \\
\text { diabetes }\end{array}$ & $\begin{array}{l}\text { Body } \\
\text { wgt. }\end{array}$ & $\begin{array}{l}\text { Blood } \\
\text { sugar }\end{array}$ & $\mathrm{pH}$ & Blood ketones* \\
\hline \multicolumn{7}{|l|}{$80-100$ day old rats } \\
\hline Normal (8)† & $\begin{array}{l}\text { Mean } \\
\text { S.D. }\end{array}$ & & $\begin{array}{l}281 \\
15.3\end{array}$ & $\begin{array}{l}115 \\
4.8\end{array}$ & $\begin{array}{l}7.45 \\
0.030\end{array}$ & 0 \\
\hline Normal acidotic (7) & $\begin{array}{l}\text { Mean } \\
\text { S.D. } \\
\text { pł }\end{array}$ & & $\begin{array}{c}259 \\
11.5 \\
0.02\end{array}$ & $\begin{array}{c}109 \\
6.9 \\
\text { ns }\end{array}$ & $\begin{array}{l}7.29 \\
0.030 \\
0.001\end{array}$ & $\begin{array}{l}1=0,1=\text { faint trace } \\
3=\text { trace, } 2=+ \text { to }++\end{array}$ \\
\hline Diabetic (6) & $\begin{array}{r}\text { Mean } \\
\text { S.D. } \\
\text { p }\end{array}$ & 3-4 weeks & $\begin{array}{l}234 \\
14.1 \\
0.001\end{array}$ & $\begin{array}{l}218 \\
75.6 \\
0.001\end{array}$ & $\begin{array}{r}7.43 \\
0.09 \\
\text { ns }\end{array}$ & $5=0,1=$ faint trace \\
\hline Diabetic acidotic (9) & $\begin{array}{l}\text { Mean } \\
\text { S.D. } \\
\text { p }\end{array}$ & 3-4 weeks & $\begin{array}{l}218 \\
30.2 \\
0.001\end{array}$ & $\begin{array}{l}269 \\
73.4 \\
0.001\end{array}$ & $\begin{array}{l}7.29 \\
0.053 \\
0.001\end{array}$ & $5=0,4=$ faint trace \\
\hline $\begin{array}{l}\text { Diabetic vs. diabetic } \\
\text { acidotic }\end{array}$ & $\mathbf{p}$ & & $\mathrm{ns} \delta$ & ns & 0.01 & \\
\hline \multicolumn{7}{|l|}{280 day old rats } \\
\hline Normal (6) & $\begin{array}{l}\text { Mean } \\
\text { S.D. }\end{array}$ & & $\stackrel{484}{5.5}$ & $\begin{array}{l}106 \\
8.6\end{array}$ & & \\
\hline Diabetic (6) & $\begin{array}{l}\text { Mean } \\
\text { S.D. } \\
\text { p }\end{array}$ & 6 months & $\begin{array}{l}356 \\
12.6 \\
0.001\end{array}$ & $\begin{array}{l}365 \\
65.0 \\
0.001\end{array}$ & & \\
\hline
\end{tabular}

* Values of less than + represent less than $10 \mathrm{mg}$. per cent acetone; t to ++ represent 10 to $20 \mathrm{mg}$. per cent acetone (12).

$\dagger$ No. animals in group.

I $\mathrm{p}$ values are the significance of difference of means of normal and experimental animals. The 80 to 100 day rats are compared with the 80 to 100 day normals and the 280 day diabetic rats with the 280 day normals.

$\S$ No significant difference $(p>0.05)$. 
ent in bone is present in the extracellular and hydration shell water. Using the formulae of Hastings and Eichelberger (15), the amount of this water was calculated, and the sodium contained in it subtracted from the total sodium in the bone.4 The remainder of the sodium was assumed to be present in association with the crystalline lattice of the bone. Accordingly, crystal sodium was calculated by dividing the concentration of total bone sodium (minus extracellular fluid sodium) in a $\mathrm{Kg}$. of bone solids by the percentage of ash found per $\mathrm{Kg}$. of solids, divided by 100 . In the calculation of bone crystal calcium, the correction for calcium contained in the chloride space has been omitted, since it is always less than $1 \mathrm{mM}$.

Expression of calculated sodium and calcium values using this reference base has the advantage of eliminating fluctuations in total ions which may be due to changes in the volume or ion content of the chloride space of bone, and also presents the data as figures that are probably close to the actual concentrations of these ions in the bone mineral. It has the disadvantage that the chloride space as calculated may not be a true measure of this moiety of bone water.

Statistical analysis of the data was done using Fisher's $t$ test for small samples.

\section{RESULTS}

Tables I through III present the results obtained. All experimental values were referred to the 80 to 100 day old normal controls, with the exception of the values for the 280 day old diabetic rats where control values were those found in the normal animals of the same age. In addition, statistical comparison of the data of diabetic versus diabetic acidotic animals was made.

In Table $I$ it can be seen that diabetes caused a significant loss of weight. Short-term diabetic rats weighed 16.8 per cent less than normal controls, while after six months the diabetic animals weighed 26.5 per cent less than their nondiabetic littermates. In addition, acidosis caused loss of weight in both groups of animals, statistically significant in the normals. The acidotic animals had a marked diuresis following $\mathrm{NH}_{4} \mathrm{Cl}$, which probably ac-

1 The formula used for the calculation of the chloride space in bone is as follows:

$$
\mathrm{CCS}=\frac{\mathrm{Cl}_{\mathrm{s}} \times \mathrm{S}}{\mathrm{Cl}_{\mathrm{p}} \div \mathrm{H}_{2} \mathrm{O}_{\mathrm{p}} \times 0.96}
$$

where

$\mathrm{CCS}=$ ml. "calculated chloride $\mathrm{H}_{2} \mathrm{O}$ " per $\mathrm{Kg}$. fat-free bone,

$\mathrm{Cl}_{\mathrm{s}}=\mathrm{mM} \mathrm{Cl}$ per $100 \mathrm{Gm}$. fat-free bone,

$\mathrm{S}=\mathrm{Gm}$. solids per $\mathrm{Kg}$. fat-free bone $\div 100$,

$\mathrm{Cl}_{\mathrm{p}}=\mathrm{mM} \mathrm{Cl}$ per L. plasma,

$\mathrm{H}_{2} \mathrm{O}_{\mathrm{p}}=\mathrm{Gm} . \mathrm{H}_{2} \mathrm{O}$ per L. plasma $\div 1,000$, and

$0.96=$ Donnan correction factor.
TABLE II

Plasma water and electrolytes

\begin{tabular}{|c|c|c|c|c|}
\hline & & $\mathrm{H}_{2} \mathrm{O}$ & $\mathrm{Na}$ & $\mathrm{Cl}$ \\
\hline $80-100$ day old rats & & $G m . / L$ & \multicolumn{2}{|c|}{$m E q . / L$} \\
\hline Normal (8)* & $\begin{array}{l}\text { Mean } \\
\text { S.D. }\end{array}$ & $\begin{array}{l}951 \\
2.2\end{array}$ & $\begin{array}{l}149 \\
3.6\end{array}$ & $\begin{array}{l}109 \\
3.1\end{array}$ \\
\hline $\begin{array}{l}\text { Normal } \\
\text { acidotic (7) }\end{array}$ & $\begin{array}{r}\text { Mean } \\
\text { S.D. } \\
\text { p! }\end{array}$ & $\begin{array}{r}952 \\
1.8 \\
\mathrm{~ns} \S\end{array}$ & $\begin{array}{c}144 \\
5.2 \\
\text { ns }\end{array}$ & $\begin{array}{r}121 \dagger \\
4.2\end{array}$ \\
\hline Diabetic (6) & $\begin{array}{r}\text { Mean } \\
\text { S.D. } \\
\text { p }\end{array}$ & $\begin{array}{c}953 \\
4.6 \\
\mathrm{~ns}\end{array}$ & $\begin{array}{c}141 \\
2.4 \\
0.01\end{array}$ & $\begin{array}{l}100 \\
\quad 4.1 \\
0.001\end{array}$ \\
\hline $\begin{array}{l}\text { Diabetic } \\
\text { acidotic (9) }\end{array}$ & $\begin{array}{r}\text { Mean } \\
\text { S.D. } \\
\text { p }\end{array}$ & $\begin{array}{c}955 \\
1.7 \\
0.01\end{array}$ & $\begin{array}{c}150 \\
4.2 \\
\text { ns }\end{array}$ & $\begin{array}{r}116 \dagger \\
5.4\end{array}$ \\
\hline $\begin{array}{l}\text { Diabetic vs. dia- } \\
\text { betic acidotic }\end{array}$ & $\mathbf{p}$ & ns & 0.001 & ns \\
\hline 280 day old rats & & & & \\
\hline Normal (6) & $\begin{array}{l}\text { Mean } \\
\text { S.D. }\end{array}$ & $\begin{array}{l}945 \\
3.5\end{array}$ & $\begin{array}{l}148 \\
3.5\end{array}$ & $\begin{array}{l}103 \\
1.3\end{array}$ \\
\hline Diabetic (6) & $\begin{array}{r}\text { Mean } \\
\text { S.D. } \\
\text { p }\end{array}$ & $\begin{array}{c}945 \\
3.5 \\
\mathrm{~ns}\end{array}$ & $\begin{array}{c}143 \\
4.1 \\
\text { ns }\end{array}$ & $\begin{array}{l}99 \\
3.9 \\
0.05\end{array}$ \\
\hline
\end{tabular}

* No. animals in group.

+ Received $\mathrm{NH}_{4} \mathrm{Cl}$.

$\mp p$ values are the significance of difference of means of normal and experimental animals. The 80 to 100 day rats are compared with the 80 to $\mathbf{1 0 0}$ day normals and the 280 day diabetic rats with the 280 day normals.

$\S$ No significant difference $(p>0.05)$.

counts for the loss of weight. Blood sugars were markedly elevated in diabetes, and were higher in the rats who had had their disease for a longer period of time. Acidosis appeared to increase the blood sugar of diabetic rats, as compared with nonacidotic diabetic animals, perhaps due to the stress of this experimental procedure, but this difference was not statistically significant. Plasma $\mathrm{pH}$ was normal in the diabetic rats, and ammonium chloride did not result in a more marked drop in the diabetic animals. $\mathrm{pH}$ fell an average of 0.14 unit in the diabetic animals and 0.16 unit in the nondiabetic animals.

Results of plasma ketone analyses were of interest in that normal animals exhibited a much more marked degree of ketosis in response to acidosis than did diabetic animals, probably as a result of the previously mentioned fact that the presence of depot fat is a necessary precursor for the development of ketosis. This finding also suggests that lowered $\mathrm{pH}$, such as occurred in the non- 
TABLE III

Basic bone data*

\begin{tabular}{|c|c|c|c|c|c|c|}
\hline & & $\mathrm{H}_{2} \mathrm{O}$ & Ash & $\mathbf{C l}$ & $\mathrm{Na}$ & $\mathrm{Ca}_{2}$ \\
\hline $80-100$ day old rats & & Gm./Kg. bone & $\%$ solids & & $m M / 100 \mathrm{Gm}$. solids & \\
\hline Normal (8) $†$ & $\begin{array}{l}\text { Mean } \\
\text { S.D. }\end{array}$ & $\begin{array}{l}234 \\
16.1\end{array}$ & $\underset{1.5}{70.0}(7)$ & $\begin{array}{l}2.69 \\
0.22\end{array}$ & $\begin{array}{c}26.1 \\
0.85\end{array}$ & $\begin{array}{l}671 \\
14.8\end{array}$ \\
\hline Normal acidotic (7) & $\begin{array}{c}\text { Mean } \\
\text { S.D. } \\
\text { pł }\end{array}$ & $\begin{array}{c}243 \\
10.4 \\
\text { ns } 8\end{array}$ & $\begin{array}{c}71.1 \text { (6) } \\
1.0 \\
\text { ns }\end{array}$ & $\begin{array}{l}2.99 \\
0.23 \\
0.01\end{array}$ & $\begin{array}{l}23.2 \\
0.41 \\
0.001\end{array}$ & $\begin{array}{l}643 \\
7.6 \\
0.01\end{array}$ \\
\hline Diabetic (6) & $\begin{array}{r}\text { Mean } \\
\text { S.D. } \\
\text { p }\end{array}$ & $\begin{array}{l}224 \\
13.2 \\
\text { ns }\end{array}$ & $\begin{array}{r}69.9 \\
2.4 \\
\text { ns }\end{array}$ & $\begin{array}{l}2.20 \\
0.26 \\
0.02\end{array}$ & $\begin{array}{c}25.1 \\
0.47 \\
\text { ns }\end{array}$ & $\begin{array}{c}657 \\
2.9 \\
\text { ns }\end{array}$ \\
\hline Diabetic acidotic (9) & $\begin{array}{r}\text { Mean } \\
\text { S.D. } \\
\text { p }\end{array}$ & $\begin{array}{l}218 \\
9.7 \\
0.05\end{array}$ & $\begin{array}{c}69.8(7) \\
2.0 \\
\text { ns }\end{array}$ & $\begin{array}{l}2.53 \\
0.16 \\
0.05\end{array}$ & $\begin{array}{l}23.4 \\
0.71 \\
0.001\end{array}$ & $\begin{array}{c}632 \\
15.3 \\
0.001\end{array}$ \\
\hline $\begin{array}{l}\text { Diabetic vs. diabetic } \\
\text { acidotic }\end{array}$ & $\mathbf{p}$ & ns & ns & ns & 0.01 & 0.05 \\
\hline \multicolumn{7}{|l|}{280 day old rats } \\
\hline Normal (6) & $\begin{array}{l}\text { Mean } \\
\text { S.D. }\end{array}$ & $\begin{array}{r}192 \\
5.8\end{array}$ & $\begin{array}{r}70.9 \\
1.4\end{array}$ & $\begin{array}{l}2.63 \\
0.35\end{array}$ & $\begin{array}{l}26.8 \\
1.04\end{array}$ & \\
\hline Diabetic (6) & $\begin{array}{r}\text { Mean } \\
\text { S.D. } \\
\text { p }\end{array}$ & $\begin{array}{l}201 \\
11.5 \\
\mathrm{~ns}\end{array}$ & $\begin{array}{c}71.3 \\
2.1 \\
\text { ns }\end{array}$ & $\begin{array}{l}2.16 \\
0.22 \\
0.02\end{array}$ & $\begin{array}{c}27.3 \\
0.88 \\
\text { ns }\end{array}$ & \\
\hline
\end{tabular}

* All data are expressed in terms of fat-free bone.

† No. animals in group.

I $\mathrm{p}$ values are the significance of difference of means of normal and experimental animals. The 80 to 100 day rats are compared with the 80 to 100 day normals and the 280 day diabetic rats with the 280 day normals.

$\S$ No significant difference $(p>0.05)$.

diabetic animals in response to hyperchloremia, inhibited normal glucose utilization, resulting in a secondary ketoacidosis which might have been responsible for the slightly greater degree of $\mathrm{pH}$ change seen in the normal animals when compared to the diabetics.

Table II presents the average values found for plasma water and electrolytes in the different groups of animals. Plasma water was lower in the older animals, as has been described during aging $(7,11)$. Diabetes did not affect plasma hydration, but there was a slight increase in plasma water in the diabetic acidotic rats. Plasma sodium and chloride concentrations were lower in the diabetic animals than in the normals. In the younger rats both these differences were statistically significant, and plasma chloride was significantly lowered in the older diabetic animals. A rapid rate of urine formation, secondary to the osmotic diuresis of hyperglycemia, which prevented as complete reabsorption of these ions as normally occurs, is the probable explanation for these findings. The high plasma chloride values in the acidotic animals were the result of the large load of intraperitoneal ammonium chloride which they had received. The normal value for serum $\mathrm{Na}$ seen in the diabetic acidotic animals, as compared to the diabetics, may have been due to retention of $\mathrm{Na}$ from the $\mathrm{NaCl}$ solution in which the $\mathrm{NH}_{4} \mathrm{Cl}$ was administered.

In Table III, it can be seen that the water and electrolyte content of the bones of diabetic animals did not differ significantly from that of the normal controls, with the exception of chloride. Although total bone water was significantly lower in the older animals, both control and diabetic, compared to the younger, as has been previously reported in association with aging $(7,11)$, the total bone sodium content was not lowered in diabetes either of short or long duration. In contrast, total bone sodium was significantly lower in both normal and diabetic animals rendered acidotic, the size of the decrease in bone sodium being similar in both groups of animals. Bone calcium also fell 
TABLE IV

Calculated bone data*

\begin{tabular}{|c|c|c|c|c|c|c|}
\hline & & $\begin{array}{l}\text { Calculated } \\
\text { chloride } \\
\text { space }\end{array}$ & $\begin{array}{c}\text { Remaining } \\
\text { water }\end{array}$ & $\begin{array}{l}\text { Chloride } \\
\text { space } \\
\mathrm{Na}\end{array}$ & $\begin{array}{c}\text { Calculated } \\
\text { "crystal" } \\
\mathrm{Na}\end{array}$ & $\begin{array}{c}\text { Calculated } \\
\text { "crystal" } \\
\mathrm{Ca}\end{array}$ \\
\hline $80-100$ day old rats & & \multicolumn{2}{|c|}{ Gm./Kg. wet bone } & $\underset{\text { wot bone }}{\text { Total } m M / K g}$ & \multicolumn{2}{|c|}{$m M / K_{8}$. crystal } \\
\hline Normal (8)† & $\begin{array}{l}\text { Mean } \\
\text { S.D. }\end{array}$ & $\begin{array}{r}174 \\
11.0\end{array}$ & $\begin{array}{l}57 \\
16.0\end{array}$ & $\begin{array}{r}26.2 \\
2.0\end{array}$ & $\begin{array}{c}325(7) \\
11.8\end{array}$ & $\begin{array}{r}9,622(7) \\
162\end{array}$ \\
\hline Normal acidotic (7) & $\begin{array}{l}\text { Mean } \\
\text { S.D. } \\
\text { pł }\end{array}$ & $\begin{array}{r}171 \\
12.8 \\
\mathrm{~ns} \S\end{array}$ & $\begin{array}{l}70 \\
9.4 \\
\mathrm{~ns}\end{array}$ & $\begin{array}{r}24.6 \\
1.5 \\
\mathrm{~ns}\end{array}$ & $\begin{array}{c}280(6) \\
7.6 \\
0.001\end{array}$ & $\begin{array}{r}8,994(6) \\
54 \quad \\
0.001\end{array}$ \\
\hline Diabetic (6) & $\begin{array}{r}\text { Mean } \\
\text { S.D. } \\
\text { p }\end{array}$ & $\begin{array}{c}148 \\
7.2 \\
0.01\end{array}$ & $\begin{array}{l}76 \\
10.0 \\
\mathrm{~ns}\end{array}$ & $\begin{array}{l}21.1 \\
0.8 \\
0.001\end{array}$ & $\begin{array}{c}322 \\
8.6 \\
\text { ns }\end{array}$ & $\begin{array}{r}9,414 \\
108 \\
\text { ns }\end{array}$ \\
\hline Diabetic acidotic (9) & $\begin{array}{r}\text { Mean } \\
\text { S.D. } \\
\text { p }\end{array}$ & $\begin{array}{c}157 \\
12.7 \\
0.02\end{array}$ & $\begin{array}{l}61 \\
18.2 \\
\mathrm{~ns}\end{array}$ & $\begin{array}{c}23.6 \\
2.2 \\
0.05\end{array}$ & $\begin{array}{c}289(7) \\
11.9 \\
0.001\end{array}$ & $\begin{array}{r}9,093(7) \\
161 \\
0.001\end{array}$ \\
\hline $\begin{array}{l}\text { Diabetic vs. diabetic } \\
\text { acidotic }\end{array}$ & $\mathbf{p}$ & ns & ns & ns & 0.001 & 0.01 \\
\hline \multicolumn{7}{|l|}{280 day old rats } \\
\hline Normal (6) & $\begin{array}{l}\text { Mean } \\
\text { S.D. }\end{array}$ & $\begin{array}{c}182 \\
11.2\end{array}$ & $\begin{array}{c}10 \\
8.2\end{array}$ & $\begin{array}{r}26.7 \\
2.7\end{array}$ & $\begin{array}{l}331 \\
13.2\end{array}$ & \\
\hline Diabetic (6) & $\begin{array}{r}\text { Mean } \\
\text { S.D. } \\
\text { p }\end{array}$ & $\begin{array}{c}158 \\
12.3 \\
0.01\end{array}$ & $\begin{array}{l}43 \\
18.3 \\
0.01\end{array}$ & $\begin{array}{r}23.0 \\
2.7 \\
\text { ns }\end{array}$ & $\begin{array}{c}343 \\
7.7 \\
\text { ns }\end{array}$ & \\
\hline
\end{tabular}

* All data are expressed in terms of fat-free bone.

† No. animals in group.

I $p$ values are the significance of difference of means of normal and experimental animals. The 80 to 100 day rats are compared with the 80 to 100 day normals and the 280 day diabetic rats with the 280 day normals.

$\$$ No significant difference $(p>0.05)$.

in both normal and diabetic acidotic animals. Bone chloride content was significantly lowered in both young and old diabetic animals, while acidosis raised the bone chloride content in both normals and diabetics, probably as a reflection of the abnormally high plasma concentrations of this electrolyte. This hypothesis is confirmed by the fact that acidosis did not significantly increase bone chloride spaces (Table IV).

\section{DISCUSSION}

While the total volume of bone water is amenable to direct measurement, the assumption that the chloride space is a true measure of the extracellular space of this tissue is open to considerable doubt. Histological studies and the investigations by Neuman, Toribara and Mulryan of synthetic hydroxyapatite (16) suggest that bone water may be divided into four moieties: 1) "true" extracellular fluid (i.e., plasma and interstitial fluid contained in the Haversian systems ; 2) intracellular water of the bone cells; 3 ) the hydration shells of the mineral crystals; and 4) water in the form of hydronium ions substituted for $\mathrm{Ca}^{++}$or $\mathrm{Na}^{++}$at the crystal surface. In previous publications the authors have assumed that the chloride space comprised only the "true" extracellular water. Forbes, Mizner and Lewis, on the other hand, have assumed that the chloride space includes the hydration shell water as well (11). Their theory is supported by two observations which suggest that our previous concept was in error. First, there appears to be exchange of ions between the bulk solution and the apatite crystal in vitro $(17,18)$, which implies that the hydration shell water must contain the same ions and be continuous with the bulk solution in vitro, and, by analogy, the extracellular fluid in vivo. Second, Neuman and associates' experiments with fresh bone indicate that the largest part of the water is bound, presumably 
as an hydration shell (16). Since most of the bone water is included in the calculated chloride space, one must deduce that the hydration shell contains chloride.

The calculation of a chloride space in bone, then, presupposes that the concentration of chloride in the hydration shell is equal to that in the extracellular fluid. This may not be a valid assumption. It is currently believed that the surfaces of bone apatite crystals are charged (19); the concentration of ions in solution in the hydration shell water must therefore be at least in part influenced by this charge, and by the ability of a particular ion, depending on its size and charge, to exchange with the crystal surface. Neuman and Neuman have shown that phosphate appears to be restricted within the hydration shell water by the crystal charge (20), and this could also be true of chloride. If this is the case, the concentration of chloride in the hydration shell may be higher than in the extracellular fluid, as in tendon water where the concentration of chloride averages 10 to 20 $\mathrm{mM}$ higher than in extracellular fluid (21) due to binding by positively charged sites on the collagen molecules. If this is the case, one is overestimating the size of the bone chloride space and assigning to it more sodium than it actually may contain, thereby underestimating the concentration of sodium in the lattice. Furthermore, the concentration of sodium in the water of hydration may vary for the same reasons as in the case of chloride, introducing still another source of error.

Using the calculated chloride space as a measure of the sum of "true" extracellular fluid and water of hydration, the remaining water in young animals constitutes some 25 per cent of total bone water. Presuming that bone cells are hydrated to the same extent as muscle cells $\left(765 \mathrm{Gm} . \mathrm{H}_{2} \mathrm{O}\right.$ per $\mathrm{Kg}$.) $(10,22)$, then marrow-free cortical bone would contain some 8.5 per cent of cells. This figure seems high, but part of the water may be present as hydronium ions. On the other hand, in older rats, where nonchloride water constitutes only 6 per cent of the total bone water, cells would constitute only 1.3 per cent, which seems low, and there would be virtually no water present as hydronium ion.

It is also puzzling that the total water content of adult bone is inadequate to hydrate bone collagen to the same extent as collagen in other parts of the body. Pure collagen, as exemplied by tendon, has a water to dry solids ratio of $2: 1$ (21). In our normal 280 day old rats, water constituted 19.2 per cent of the total bone. Of the total solids (808 Gm.), ash weight constituted 70.9 per cent or $572 \mathrm{Gm}$. Dry collagen constituted almost 100 per cent of the remaining solids (23), or $236 \mathrm{Gm}$. If this collagen were hydrated to the same extent as tendon, it would, then, command the presence of some $472 \mathrm{Gm}$. of water, more than twice the total water content of adult bone found by us and other workers (11). Presuming that bone contains a considerable amount of crystalline water of hydration, as well as water in the Haversian systems, and a small amount of intracellular water, one is reduced to visualizing collagen in mature bone as virtually a "dry" substance. This same conclusion has been reached by Robinson (24), and similar findings in enamel have been reported by Deakins (25). One is tempted to speculate, in the light of this finding, that the dehydration of collagen in bone occurs during skeletal development by the substitution of calcium and phosphate ions directly into the collagen fiber, in exchange for hydronium or hydroxyl ions. In other words, the formation of the crystalline structure of bone may occur actually within the fibers of collagen by means of a chemical exchange between the water of this substance and the ions forming the bone crystal. The marked decline in total bone water from weanling to old rats $(7,10,11)$ and the demonstration of calcification centers inside the collagen fibrils of embryonic bone (26) support this concept.

Despite these grave reservations as to the validity of the calculated chloride space in bone, it should be realized that some sodium in bone does exist that is not present as part of the mineral lattice, that the amount of this sodium may vary, and that the only possible method of estimating this variation at present is by the use of such a calculated chloride space. The quantitative accuracy of the data derived by this means is certainly open to criticism.

Table IV and Figures 1 and 2 present values calculated from the basic data for the water, sodium and calcium content of bone.

In the three groups of nondiabetic animals, the only significant changes found in either total bone water or calculated chloride spaces was a decrease 


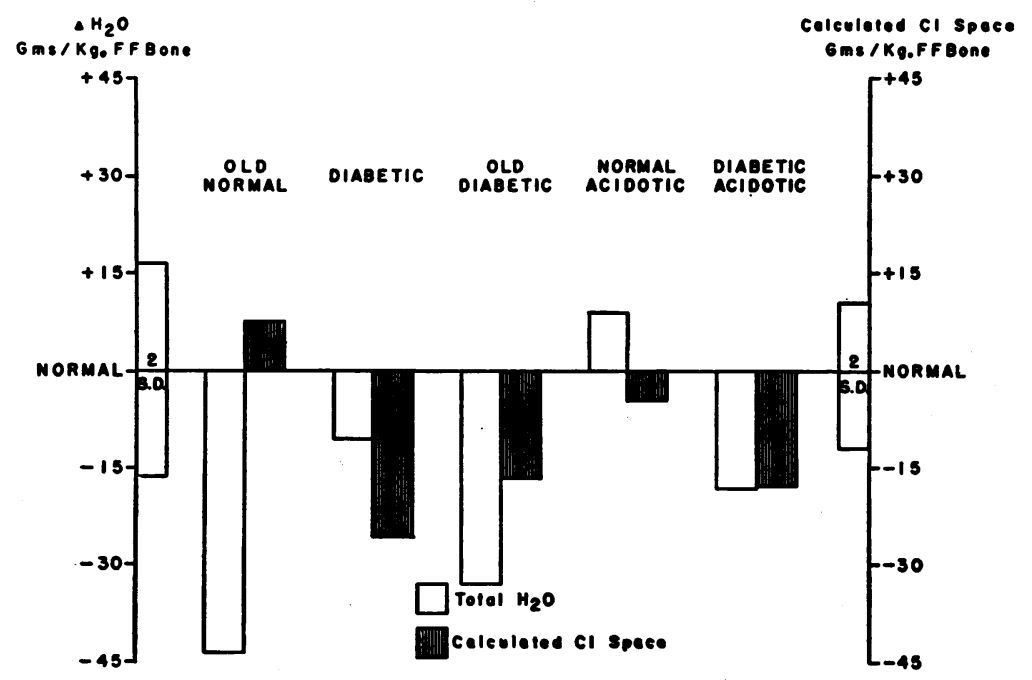

Fig. 1. Changes in Bone Water

The bars represent changes in total bone water and calculated $\mathrm{Cl}$ space in the old normals and the experimental groups, as compared with the values found in the normal 80 to 100 day control animals. One standard deviation above and below normal is shown on the scale for both total water and calculated $\mathrm{Cl}$ space.

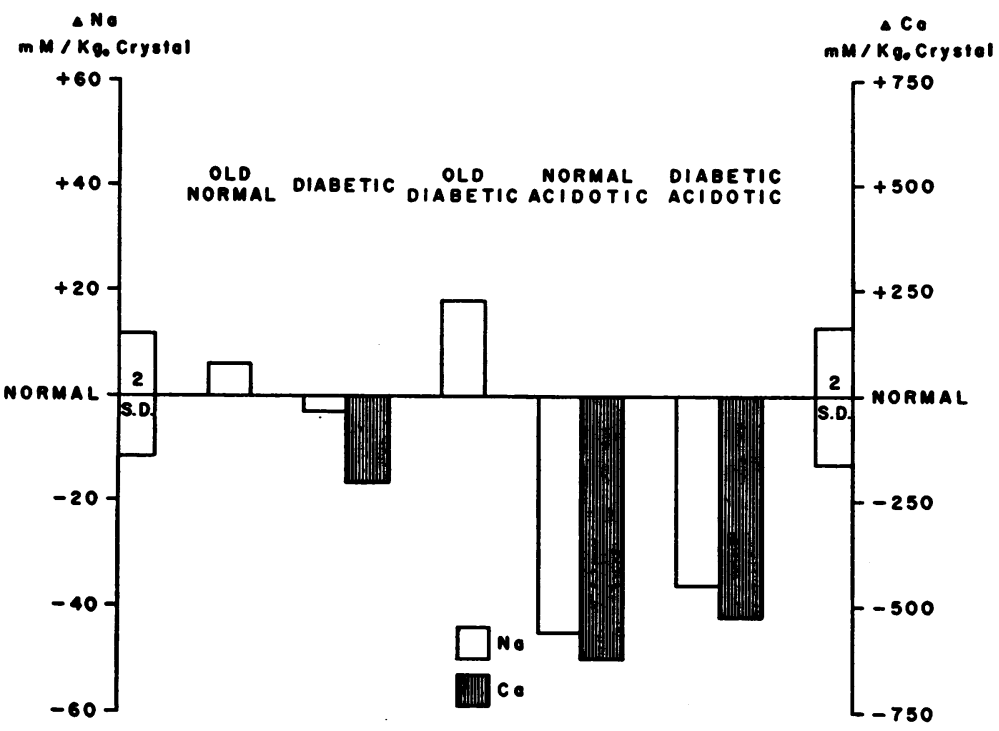

Fig. 2. Changes in Bone Crystal Sodium and Calctum

The bars represent changes in the concentration of calculated "crystal" $\mathrm{Na}^{+}$and $\mathrm{Ca}^{++}$in the old normals and experimental groups, as compared with the values found in the normal 80 to 100 day control animals. One standard deviation above and below normal values is shown on the scale for both $\mathrm{Na}^{+}$and $\mathrm{Ca}^{++}$. 
in the total bone water of the older animals, consistent with previous reports (Table IV and Figure 1). Since the calculated chloride space did not decrease with age, this represented a significant decrease $(p<0.01)$ in the remaining fraction of the bone water, which fell from 25 per cent of the total bone water in the 80 to 100 day rats to 5 per cent in the older animals.

In the diabetic animals, total bone water was lowered significantly, compared to the normal 80 to 100 day controls, in the acidotic group. This lowering appeared to be a combination of the stress of diabetes and acidosis in these animals, since the values for total bone water in the nonacidotic animals did not differ significantly from the normal controls, nor were the values for the diabetic-acidotic rats significantly different from those for the nonacidotic diabetic animals. On the other hand, the calculated chloride space was significantly lower in all three groups of diabetic animals, compared with the normal 80 to 100 day controls. This change was also significant when the values for the older diabetic animals were compared with the values found in the older controls. The calculated chloride space in the 80 to 100 day old diabetics was 15 per cent less than in the 80 to 100 day controls, and 10 per cent less in the diabetic-acidotic animals, compared with the same controls. In the older animals, the calculated chloride space was 13 per cent less than in the control animals of the same age. Acidosis, as produced in these experiments, did not significantly alter the size of the calculated chloride space in either normal or diabetic animals. The mechanisms which underlie these apparent changes in the volume and distribution of bone water are as yet unknown. In the case of the reduced size of the calculated chloride spaces in the diabetic animals, one might speculate that there was a general reduction in total body extracellular fluid volume, as a result of osmotic diuresis, which was reflected in the calculated chloride space of bone. Since no measurements of total extracellular fluid were made in these animals, the validity of this concept cannot be determined.

Table IV and Figure 2 present calculated values for bone crystal sodium and calcium. It is apparent from these calculated values that bone crystal sodium concentrations were almost identi- cal in the short-term diabetic animals with those found in the normal animals. There was, however, an increase in bone crystal sodium in the bones of the older animals, as has already been described by the authors and other investigators $(7,8,11)$. This increase was actually greater in the old diabetic rats than in the normals, confirming the impression that uncontrolled diabetes of this type, despite causing a lowered serum sodium concentration, did not decrease the store of sodium in the bone crystal. It is of interest to note that age, rather than weight, is apparently the determining factor in bone crystal sodium concentration, since the diabetic rats weighed 18 to 20 per cent less than the normal controls.

In both normal and diabetic animals, however, acidosis caused a marked fall in the concentration of bone crystal sodium. In the normal animals bone crystal sodium fell from 325 to $280 \mathrm{mM}$ in response to acidosis, a decrease of 13.8 per cent, while in the diabetics it dropped from 322 to 289 , or 9.9 per cent From these data, it would appear that there was little difference in the response of bone crystal sodium of the normal and the diabetic rats to the stimulus of acidosis.

The mobilization of bone crystal sodium observed in these rats in response to hyperchloremic acidosis is comparable to that observed by the authors in adult dogs, where in response to acute pure sodium deficiency some 11 per cent of bone crystal sodium was removed (9) and to the 11 per cent fall found by Levitt, Turner, Sweet and Pandiri in rats (27). Lesser degrees of bone sodium depletion were observed by Edelman, James, Baden and Moore in dietary sodium depletion of dogs (5.8 per cent) (28) and by Lobeck and Forbes ( 5.5 per cent) (29) in rats dying in acute acidosis 72 hours after the injection of alloxan monohydrate. It is of interest that in the latter experiments the degree of sodium depletion of bone was less than half that reported here, despite greater decreases in plasma $\mathrm{pH}$ and significantly decreased serum sodium concentrations. It is possible that adrenal stimulation accounted for this, since their animals were moribund at the time of sacrifice. Bergstrom and Wallace, using a dialysis technique identical with that used in the present series, but allowing their rats to equilibrate for 24 hours in the absence of exogenous sodium, were able to mobilize 31 per 
cent of the "extra" sodium of bone (8). No bone waters are available in this series, and furthermore, since their values were expressed in terms of wet bone rather than crystal solids, it is diffcult to compare them with our values.

Bergstrom and Wallace noted a fall in bone calcium in response to acidosis similar to that reported here, although this decrease was not statistically significant (8). In their animals, calcium fell from 8,000 to $7,800 \mathrm{mEq}$. per $\mathrm{Kg}$. of wet bone, or 2.5 per cent. In the present series, bone calciums were comparable in the normal and diabetic animals, and acidosis caused a fall of 7 per cent in bone crystal calcium in the bones of the normal rats, and a drop of 3.4 per cent in the diabetic animals. These changes were both highly significant.

It would appear in these animals, that loss of bone sodium in response to acidosis was not accompanied by any major gain in water, and in fact there was a decreased amount of nonextracellular water in the diabetic animals. Hence no exchange of sodium for hydronium ion can be postulated. Nor, apparently, was sodium exchanged for calcium in the crystals, since bone crystal calcium also fell. An exchange of hydrogen ion for sodium and calcium cannot be postulated in the light of Neuman and Neuman's belief that hydrogen ion exchange at the crystal surface occurs only when hydrogen is present as hydronium or hydroxyl ion (19). It is probable, therefore, that actual dissolution of the crystalline matrix occurs in acidosis; some confirmation of this is found clinically in the demineralization of bone observed in conditions of chronic acidosis $(30,31)$. It is also probable that, in these animals, dissolution of organic matrix also occured, since there was virtually no change in the percentage of ash in the acidotic bones. If 7 per cent of the crystalline matrix had been lost, as suggested by the fall in calcium in the nondiabetic acidotic animals unaccompanied by a loss of organic solids, one would have expected to find a lowering of the ash to organic solids ratio in these bones. Furthermore, the ratio of calcium to the other mineral ions must have decreased, since a decrease in the concentration of this ion was observed in relation to both total bone solids and bone ash.

The syndrome of alloxan diabetes in the rat, while differing in many important respects from the spontaneous diabetes occurring in humans, does include hyperglycemia, glycosuria and polyuria, which might be expected to reduce stores of body sodium. However, from the data presented, it would appear that untreated alloxan diabetes in the presence of an adequate dietary intake of sodium exerted little or no effect upon body sodium stores, as exemplified by the storage of sodium in bone, despite the presence of a lowered serum sodium in these animals. It should also be noted that serum sodium was high in the diabeticacidotic animals who lost considerable quantities of bone sodium. Apparently, then, the removal of sodium from bone is not completely dependent on extracellular fluid levels of this ion in the absence of acidosis. The concentration of extracellular fluid sodium may, however, play some part in the mobilization of bone sodium. We were able to mobilize some $70 \mathrm{mM}$ of sodium in excess of that lost from the extracellular fluid, from dogs dialyzed against a low-sodium bath (9). In these animals plasma sodium fell $7 \mathrm{mM}$ per L., while plasma $\mathrm{pH}$ remained normal. Much more sodium was mobilized from a second group of animals in whom plasma sodium fell $18 \mathrm{mM}$ per L., accompanied by a fall in plasma $\mathrm{pH}$ (9). In the present series of rats, more sodium and calcium were mobilized in the normal acidotic animals who had a plasma sodium concentration of $144 \mathrm{mM}$ than in the diabetic-acidotic animals with a plasma sodium of $150 \mathrm{mM}$ per L. Plasma $\mathrm{pH}$ was comparable in the two groups. These findings suggest that either lowered extracellular fluid sodium in the presence of normal $\mathrm{pH}$ or acidosis in the presence of normal extracellular fluid sodium may cause a loss of bone sodium, but that maximal loss of bone sodium occurs when both of these factors are present.

\section{SUMMARY}

1. Untreated alloxan diabetes does not alter the total water or crystal sodium and calcium content of bone. It does diminish the size of the "calculated chloride space" of bone.

2. Acute hyperchloremic acidosis causes a fall in bone crystal sodium (10.2 per cent) and calcium (3.5 per cent) in diabetic rats which is comparable with the fall in bone crystal sodium (13.8 per cent) and calcium ( 7.0 per cent) obtained in normal rats. 
3. A discussion of the present state of knowledge of bone water, and those factors limiting the accuracy of the "calculated chloride space" in bone, is presented.

\section{ACKNOWLEDGMENT}

The authors are indebted to Miss Anne Brooks and Mrs. Barbara Paganelli for technical assistance.

\section{REFERENCES}

1. Weissberg, J., McGavack, T. H., Shearman, A. M., and Drekter, I. J. Electrolytic balance in uncontrolled and controlled diabetic ketosis and acidosis. J. clin. Endocr. 1949, 9, 1259.

2. Darrow, D. C., and Pratt, E. L. Retention of water and electrolyte during recovery in a patient with diabetic acidosis. J. Pediat. 1952, 41, 688.

3. Seldin, D. W., and Tarail, R. The metabolism of glucose and electrolytes in diabetic acidosis. J. clin. Invest. 1950, 29, 552.

4. Nabarro, J. D. N., Spencer, A. G., and Stowers, J. M. Metabolic studies in severe diabetic ketosis. Quart. J. Med. 1952, 21, 225.

5. Harrison, H. E., Darrow, D. C., and Yannet, $H$. The total electrolyte content of animals and its probable relation to the distribution of body water. J. biol. Chem. 1936, 113, 515.

6. Shohl, A. T. Mineral Metabolism. New York, Reinhold Publishing Corp., 1939.

7. Nichols, G., Jr., and Nichols, N. The role of bone in sodium metabolism. Metabolism 1956, 5, 438.

8. Bergstrom, W. H., and Wallace, W. M. Bone as a sodium and potassium reservoir. J. clin. Invest. 1954, 33, 867.

9. Nichols, G., Jr., and Nichols, N. Changes in tissue composition during acute sodium depletion. Amer. J. Physiol. 1956, 186, 383.

10. Nichols, N., and Nichols, G., Jr. Effect of large loads of sodium on bone and soft tissue composition. Proc. Soc. exp. Biol. (N. Y.) 1957, 96, 835.

11. Forbes, G. B., Mizner, G. L., and Lewis, A. Effect of age on radiosodium exchange in bone (rat). Amer. J. Physiol. 1957, 190, 152.

12. Page, O. C. Clinical application of a simple qualitative serum acetone test in diabetes mellitus. New Engl. J. Med. 1953, 248, 295.

13. Wilson, D. W., and Ball, E. G. A study of the estimation of chloride in blood and serum. J. biol. Chem. 1928, 79, 221.

14. Berry, J. W., Chappell, D. G., and Barnes, R. B. Improved method of flame photometry. Industr. engin. Chem. 1946, 18, 19.

15. Hastings, A. B., and Eichelberger, L. The exchange of salt and water between muscle and blood. I. The effect of an increase in total body water pro- duced by the intravenous injection of isotonic salt solutions. J. biol. Chem. 1937, 117, 73.

16. Neuman, W. F., Toribara, T. Y., and Mulryan, B. J. The surface chemistry of bone. VII. The hydration shell. J. Amer. chem. Soc. 1953, 75, 4239.

17. Stoll, W. R., and Neuman, W. F. The uptake of sodium and potassium ions by hydrated hydroxyapatite. J. Amer. chem. Soc. 1956, 78, 1585.

18. Neuman, W. F., Toribara, T. Y., and Mulryan, B. J. The surface chemistry of bone. IX. Carbonate: phosphate exchange. J. Amer. chem. Soc. 1956, 78, 4263.

19. Neuman, W. F., and Neuman, M. W. The nature of the mineral phase of bone. Chem. Rev. 1953, 53, 1.

20. Neuman, W. F., and Neuman, M. W. The Chemical Dynamics of Bone Mineral. Chicago, University of Chicago Press, 1958.

21. Nichols, G., Jr., Nichols, N., Weil, W. B., and Wallace, W. M. The direct measurement of the extracellular phase of tissues. J. clin. Invest. 1953, 32, 1299.

22. Schwartz, R., Cohen, J., and Wallace, W. M. Tissue electrolyte changes of the whole body, muscle, erythrocyte, and plasma of rats on a potassium deficient diet. Amer. J. Physiol. 1953, 172, 1.

23. McLean, F. C., and Urist, M. R. Bone. Chicago, The University of Chicago Press, 1955, p. 24.

24. Robinson, R. A. Personal Communication.

25. Deakins, $M$. Changes in the ash, water, and organic content of pig enamel during calcification. J. dent. Res. 1942, 21, 429.

26. Jackson, S. F., and Randall, J. T. Fibrogenesis and the formation of matrix in developing bone in Bone Structure and Metabolism. Ciba Foundation Symposium, G. E. W. Wolstenholme and C. M. O'Connor, Eds. Boston, Little, Brown and Co., 1956, p. 47.

27. Levitt, M. F., Turner, L. B., Sweet, A. Y., and Pandiri, D. The response of bone, connective tissue, and muscle to acute acidosis. $\mathrm{J}$. clin. Invest. 1956, 35, 98.

28. Edelman, I. S., James, A. H., Baden, H., and Moore, F. D. Electrolyte composition of bone and the penetration of radiosodium and deuterium oxide into dog and human bone. J. clin. Invest. 1954, 33, 122.

29. Lobeck, C. C., and Forbes, G. B. The response of bone to alloxan-diabetic acidosis in the rat. $\mathrm{Me}$ tabolism 1958, 7, 133.

30. Jaffe, H. L., Bodansky, A., and Chandler, J. P. Ammonium chloride decalcification, as modified by calcium intake: The relation between generalized osteoporosis and ostitis fibrosa. J. exp. Med. 1932, 56, 823.

31. Bradley, S. E. The Pathologic Physiology of Uremia in Chronic Bright's Disease. Springfield, Ill., Charles C Thomas, 1948. 